\title{
Effect of statins on development of post-thrombotic syndrome: cohort study
}

\section{Efecto de las estatinas en el desarrollo de síndrome postrombótico: estudio de cohorte}

Héctor J. Peroni*, María F. Grande-Ratti, Fernando J. Vázquez, Fernán B. González de Quirós, María L. Posadas-Martínez, and Diego H. Giunta

Department of Medical Clinic, Hospital Italiano de Buenos Aires, Buenos Aires, Argentina

\begin{abstract}
Objective: The objective of the study was to evaluate the association between statin consumption and development of posthrombotic syndrome (PTS). Methods: Retrospective cohort study which included patients with a first episode of deep vein thrombosis (DVT) between 06/2006 and 12/2017 included in the Institutional Registry of Thromboembolic Disease of the Italian Hospital of Buenos Aires, Argentina. Exposure to statin use (SU) was considered between the 30 days before and up to 180 days after the diagnosis of DVT. PTS was defined as recorded dataset on registry. The development of PTS was evaluated with Cox proportional hazards model, raw, and adjusted hazard ratios (HR) were reported. Confusion was considered by indication of SU and a propensity score (PS) was used for adjustment. We reported HR with their $95 \%$ confidence interval (Cl); $p<0.05$ was considered statistically significant. Results: Of 1,393 patients, 905 were included for the analysis, of which 273 were SU and 632 non-SU (NSU). At follow-up, incidence of PTS was: 6.59\% (18) in the SU group and 8.07\% (51) in the NSU group, with $p=0.412$. Crude HR for PTS for SU was not significant (0.78; 95\% Cl: 0.43-1.41; $p=0.414)$. Adjusted HR of SU by age, sex, non-steroidal anti-inflammatory drugs, corticosteroids, immobility, anticoagulant, high blood pressure, diabetes, dyslipidemia, chronic renal failure, coronary heart disease, stroke, heart failure, and cancer disease was 0.45 (95\% Cl: 0.13-1.5; $p=0.196$ ) for PTS. While HR for the development of PTS adjusted by age, sex, non-steroidal anti-inflammatory drugs, corticosteroids, immobility, anticoagulant treatment, cancer disease and PS of the SU was 0.52 (95\% Cl: $0.17-1.66 ; p=0.272)$. Conclusion: No statistically significant association was found between $C E$ and the development of SPT, although there were a small number of events detected in both groups.
\end{abstract}

Key words: Venous thrombosis. Hydroxymethylglutaryl-CoA reductase inhibitors. Post-thrombotic syndrome. Epidemiology.

\section{Resumen}

Objetivo: Explorar la asociación entre consumo de estatinas (CE) y desarrollo de síndrome postrombótico (SPT). Método: Cohorte retrospectiva con pacientes con primer episodio de trombosis venosa profunda (TVP) entre el 06/2006 y el 12/2017, incluidos en el Registro Institucional de Enfermedad TromboEmbólica (RIET) del Hospital Italiano de Buenos Aires. Se consideró exposición al CE entre los 30 días previos y hasta 180 días posterior al diagnóstico de TVP. Se definió SPT según constaba este dato en la base de seguimiento del RIET. Se evaluó el desarrollo de SPT con un modelo de

Correspondence:

*Héctor J. Peroni

E-mail: hector.peroni@ hospitalitaliano.org.ar

Available online: 02-03-2021

Date of reception: 11-09-2019

Date of acceptance: 04-17-2020

DOI: 10.24875/ACME.M20000147
Arch Cardiol Mex (Eng). 2020;90(4):354-362
www.archivoscardiologia.com

Arch Cardiol Mex (Eng). 2020;90(4):354-362
www.archivoscardiologia.com 2604-7063 / @ 2020 Instituto Nacional de Cardiología Ignacio Chávez. Published by Permanyer. This is an open access article under the CC BY-NC-ND license (http://creativecommons.org/licenses/by-nc-nd/4.0/). 
riesgos proporcionales de Cox, reportando hazard ratios $(H R)$ crudas y ajustadas. Se consideró la confusión por indicación del CE y se utilizó un propensity score (PS) para el ajuste del riesgo estimado, reportando los HR con sus intervalos de confianza del 95\% (IC 95\%). Resultados: Se incluyeron 905 pacientes, de los cuales 273 fueron CE y 632 no consumidor de estatinas (NCE). Al seguimiento, la incidencia de SPT fue: 6.59\% (18) en el grupo CE y $8.07 \%$ (51) en el grupo NCE, con $p=0.412$. La razón de riesgo para el desarrollo de SPT de CE resultó no significativa (HR cruda: 0.78 ; IC 95\%: $0.43-$ 1.41; $p$ = 0.414). La HR de CE ajustada por edad, sexo, antiinflamatorios no esteroideos, corticosteroides, inmovilidad, anticoagulante, hipertensión arterial, diabetes, dislipidemia, insuficiencia renal crónica, enfermedad coronaria, accidente cerebrovascular, insuficiencia cardiaca y enfermedad oncológica fue 0.45 (IC 95\%: 0.13-1.5; $p=0.196$ ). La HR del CE ajustado por edad, sexo, antiinflamatorios no esteroideos, corticosteroides, inmovilidad, tratamiento anticoagulante, enfermedad oncológica y PS fue de 0.52 (IC 95\%: 0.17-1.66; $p=0.272$ ). Conclusiones: El CE no se asoció con menor SPT, aunque hubo escaso número de eventos detectados.

Palabras clave: Trombosis venosa. Inhibidores de hidroximetilglutaril-CoA reductasa. Síndrome postrombótico. Epidemiología.

\section{Introduction}

Deep vein thrombosis (DVT) is a disease that has an annual incidence of one case per 1000 population-year ${ }^{1,2}$. Its evolution can predispose to different complications such as pulmonary thromboembolism (PTE), hemorrhages, recurrent DVT, and/or development severe post-thrombotic sequelae ${ }^{3}$.

One of the most relevant chronic complications is post-thrombotic syndrome (PTS), which is clinically characterized by chronic pain, edema, and heaviness of the affected limb. In severe cases, venous ulcers can develop. PTS occurs in between 17 and $35 \%$ within the $1^{\text {st }}$ year and can reach a 2-year cumulative incidence of $50 \%{ }^{4}$.

PTS is known to be the result of the venous hypertension that follows the development of valve incompetence (a consequence of the damage suffered by venous valves at the time of the acute thrombotic episode and venous rechanneling phase), reflux, and venous obstruction. At these phases, different inflammatory components that represent one of the determining factors for the development of PTS do act ${ }^{5}$. In this context, statins might help decrease chronic inflammation due to their pleiotropic and anti-inflammatory effect, generated by acting on the regulation, expression downregulation and secretion of different pro-inflammatory factors ${ }^{6,7}$. This way, they might decrease the consequent development of PTS in patients who have had DVT ${ }^{8}$.

Given that PTS is largely generated by the inflammatory process that occurs in DVT-affected veins, and since statins exhibit a powerful pleiotropic effect that acts by decreasing inflammation, we wondered if there is an association between statin use (SU) and the development of PTS after the first DVT episode.

\section{Materials and methods}

A retrospective cohort was designed, which was comprised by adult patients with a first episode of DVT and who were included in the Hospital Italiano de Buenos Aires (HIBA) Thromboembolic Disease Institutional Registry (RIET - Registro Institucional de Enfermedad TromboEmbólica) between June 2006 and December 2017. Patients who refused to grant RIET oral informed consent and those without telephonic follow-up were excluded from the study.

HIBA is a high-complexity university hospital of the Autonomous City of Buenos Aires that operates as an integrated health network in Argentina. It has 18 outpatient care centers, with approximately 750 beds. Its care system offers comprehensive medical services to a population of 150,000 institutional prepayment affiliates (Italian Hospital Health Plan [PSHIBA - Plan de Salud del Hospital Italiano]), which guarantees exclusive and comprehensive care within this system. All information is centralized in a single electronic medical record $(E M R)^{9,10}$, which concentrates all administrative information (e.g., paraclinical investigations, appointment requests, outpatient appointments, hospital admissions, medication use) and all clinical information (health problems, clinical diagnoses, medical evolution notes, imaging and laboratory test results, among others). Health problems or comorbidities are automatically encoded by a terminology server with a local thesaurus that maps and encodes the information using SNOMED-CT controlled terms ${ }^{11-14}$.

All variables of this study were collected from the information contained in RIET's systematic evaluation, thus representing a high-quality secondary database. Since 2006, RIET operates as a prospective registry of venous thromboembolic disease (VTD) incident cases, 
designed, and conducted by the Internal Medicine Research Area of the Medical Clinic Department. Therein, patients corresponding to all medical coverages (not restricted to PSHIBA) are included in the study. DVTs are diagnosed by venous Doppler ultrasound of the lower limbs. The included veins were: soleus plexus or calf veins with involvement of the arch, posterior and anterior tibial veins, popliteal vein, femoral vein (superficial femoral), saphenous arch, external iliac vein, inferior and superior gluteal veins, and internal iliac vein.

For the purposes of this study, the exposed group was made up of patients who were receiving statins ${ }^{15}$. atorvastatin, rosuvastatin, simvastatin, pravastatin, fluvastatin, and lovastatin. A SU was defined as a patient who has a pharmacy purchase record and/or has the use of statins reported on the EMR within the 30 previous days and up to 180 days after the diagnosis of the first DVT episode.

All patients were prospectively followed through EMR systematic review and with information obtained by RIET systematic telephonic follow-up. Follow-up initiation was the index date of the first DVT episode. Patients were followed-up until the date of death, loss to follow-up or administrative study termination.

PTS events were collected with multiple strategies by means of: (a) an adaptation of the Villalta questionnaire in telephonic evaluations ${ }^{16}$ and (b) EMR review (to detect the encoded problem or clinical diagnosis). Cases of death and their dates were detected using secondary databases (hospital admission databases to detect in-hospital deaths) and primary capture (registration cancellation due to death, with this data being restricted only to PSHIBA patients; and death reported by relatives on telephonic follow-up, regardless of coverage).

According to the sample size calculation, for a power of $80 \%$, with an alpha error probability of approximately $5 \%$ and a two-tailed test, at least 100 patients are required for each group, assuming an incidence of 0.5 for the development of PTS in the group of non-SU (NSU) and 0.3 for the SU group. In turn, the association between SU and PTS adjusted for propensity score (PS) was assessed. To evaluate this association, 10 events are required for each variable included in the model. Considering a multivariate model with at least six variables, 60 PTS events are required.

PS was used with the purpose to solve the natural confounding bias caused by the SU indication due to the observational design without exposure randomization. Taking into account that the general population has a high mortality rate, and that this may interfere with the development of PTS, we performed a sensitivity analysis with regression models that consider competitive events. Fine and Gray ${ }^{17,18}$ regression models were used considering death as a competitive event. The variables used for PS were the following: age (odds ratio [OR]: 1.01; 95\% confidence interval [Cl]: 1.00-1.03), female gender (OR: 0.88; 95\% Cl: $0.61-$ 1.25 ), high blood pressure (HBP) (OR: 0.86; 95\% IC: $0.57-1.30$ ), coronary artery disease (OR: $2.26 ; 95 \%$ Cl: 1.33-3.84), diabetes mellitus (DM) (OR: 1.30; 95\% Cl: 0.78-2.14), dyslipidemia (DLP) (OR: 8.76; 95\% Cl: 5.91-12.97), stroke (OR: 1.78; 95\% Cl: 1.07-2.96), congestive heart failure (CHF) (OR: 1.09; $95 \% \mathrm{Cl}: 0.65-$ 1.82), and chronic kidney failure (CKF) (OR: $0.87 ; 95 \%$ Cl: 0.52-1.45). Sub-hazard ratios (sHR) are presented with their $95 \%$ Cls.

Quantitative variables were described as the mean and standard deviation (SD) or median and interquartile range (IQR) according to the observed distribution, and categorical variables, as absolute frequency and percentage. Proportions between both groups were compared with the chi-square test or Fisher's exact test, according to the assumptions. Means were compared with Student's t-test and medians, with Mann-Whitney's test. To evaluate the main study hypothesis, the time to the development of the PTS event in both groups was estimated with the Kaplan-Meier method. For this, the following dates were recorded: first DVT event, last follow-up, PTS, and death. End-of-follow-up date was regarded as whichever of the following occurred first: PTS development, death, or date of last contact. Time-to-event for both dependent variables was evaluated in months. Incidence densities were estimated in both groups and presented with their 95\% Cls per 100 persons/year. The incidence ratios between SU and NSU were estimated and presented with their $95 \% \mathrm{Cls}$. HRs were estimated with their $95 \% \mathrm{Cls}$ using a Cox proportional hazards regression bivariate model. Variables statistically associated with the development of PTS were regarded as potential confounders, and those considered of clinical importance, as confounders. A multivariate Cox proportional hazards model was used to adjust for these potential confounders. The confounding variables used for adjustment were the following: age, gender, non-steroidal anti-inflammatory drugs (NSAIDs), corticosteroids, immobility, anticoagulant treatment, HBP, DM, DLP, CKF, coronary heart disease, CVA, CHF, and oncological disease. A $p<0.05$ was considered statistically significant. STATA 13 statistical software was used.

The study was carried out in full accordance with current national and international ethical regulations. 
Table 1. Comparison between included versus excluded subjects (due to lack of follow-up)

\begin{tabular}{|c|c|c|c|}
\hline & Included ( $\mathrm{n}=905$ ) & Excluded ( $n=488$ ) & p-value \\
\hline Pulmonary embolism concomitant with DVT & $20.77 \%(188)$ & $21.11 \%(103)$ & 0.884 \\
\hline Statin & $30.17 \%(273)$ & $16.39 \%(80)$ & 0.001 \\
\hline Age, years * & $78(16)$ & $76(16)$ & 0.001 \\
\hline Female gender & $63.54 \%(575)$ & $60.25 \%(294)$ & 0.227 \\
\hline Body mass index ${ }^{\dagger}$ & 27.28 (6.02) & $27.42(5.42)$ & 0.675 \\
\hline $\begin{array}{l}\text { Comorbidities } \\
\text { Charlson Score } \\
\text { Smoking } \\
\text { High blood pressure } \\
\text { Coronary artery disease } \\
\text { Diabetes } \\
\text { Dyslipidemia } \\
\text { Stroke } \\
\text { Heart failure } \\
\text { Chronic kidney failure } \\
\text { Oncological disease } \\
\text { COPD } \\
\text { NSAIDs consumption }\end{array}$ & $\begin{array}{c}2(3) \\
6.74 \%(61) \\
61.55 \%(577) \\
9.06 \%(82) \\
10.28 \%(93) \\
45.41 \%(411) \\
9.72 \%(88) \\
9.94 \%(90) \\
10.94 \%(99) \\
28.84 \%(261) \\
10.72 \%(97) \\
23.43 \%(212)\end{array}$ & $\begin{array}{c}2(4) \\
7.17 \%(35) \\
65.16 \%(318) \\
7.58 \%(37) \\
12.70 \%(62) \\
47.13 \%(230) \\
5.94 \%(29) \\
10.66 \%(52) \\
8.61 \%(42) \\
33.40 \%(163) \\
11.07 \%(54) \\
23.98 \%(117)\end{array}$ & $\begin{array}{l}0.417 \\
0.761 \\
0.183 \\
0.346 \\
0.169 \\
0.540 \\
0.015 \\
0.676 \\
0.168 \\
0.078 \\
0.842 \\
0.818\end{array}$ \\
\hline
\end{tabular}

*Median (interquartile range).

${ }^{\dagger}$ Mean ( \pm standard deviation).

DVT: deep-vein thrombosis; COPD: chronic obstructive pulmonary disease; NSAIDs: non-steroidal anti-inflammatory drugs.

All study data were handled with the highest confidentiality. The protocol of this project was evaluated and approved by the institutional ethics committee (number 2453).

\section{Results}

Of a total of 1393 potentially includable patients who had a confirmed first DVT episode and were included in the RIET, 488 were excluded due to the lack of telephonic follow-up or death in the same episode (Table 1). Nine-hundred and five patients were included for analysis, of which 273 were SU and 632 were NSU (Fig. 1).

Regarding baseline differences between SU and NSU patients, the statistically significant differences were: older age (77.46 vs. 73.65 years; $p<0.001$ ), higher rate of HBP (76.92 vs. $54.91 \% ; p<0.001$ ), coronary artery disease (18.32 vs. $5.06 \%$; $p<0.001$ ), DM (16.12 vs. $7.75 \%$; $p<0.001)$, DLP (80.95 vs. $30.06 \%$; $p<0.001)$, stroke (17.58 vs. $6.33 \%$; $p<0.001$ ), heart failure (15.02 vs. $7.75 \% ; p<0.001)$, CKF (14.29 vs. $9.49 \% ; p=0.034)$, and previous use of NSAIDs (28.94 vs. $21.04 \% ; p=0.010$ ), in all SUs results versus those of NSUs, respectively. Table 2 presents all evaluated characteristics and the comparison between SU and NSU.
Most patients (51\%) received atorvastatin. Table 3 shows SUs details, with the frequencies and doses of each drug.

The SU group had a higher anticoagulation rate in comparison with the NSU group (91 vs. $86 \% ; p=0.036$ ). The most prescribed type of anticoagulant was Vitamin $\mathrm{K}$ antagonists (VKA). $<1 \%$ in both groups received new oral anticoagulants (NOA). About $91.21 \%$ (249) of SUs were anticoagulated $(50.92 \%$ with low molecular weight heparin, $54.21 \%$ with $\mathrm{VKA}$, and $0.37 \%$ with NOA), while $86.23 \%(545)$ of the NSU group were anticoagulated (49.37\% with low molecular weight heparin, $46.20 \%$ with VKA, and $0.63 \%$ with NOA), with the difference being significant $(p=0.036)$.

The number of PTS events detected during follow-up was 18 in the SU group and 51 in the NSU group. Median overall cohort follow-up time was 15 months (IQR: 0-38). Table 4 shows the events detected during follow-up.

\section{Association between SU and PTS}

PTS incidence density in the SU group was 3.69 (95\% Cl: 2.22-6.12) per 100 persons/year, and 4.68 (95\% Cl: 3.43-6.38) per 100 persons/year in the NSU group. Incidence density ratio was 0.79 (95\% $\mathrm{Cl}$ : 0.4-1.46) 
Table 2. Baseline characteristics of included patients with DVT by SU or NSU group

\begin{tabular}{|c|c|c|c|}
\hline & SU (n = 273) & NSU ( $n=632$ ) & $p$-value \\
\hline $\begin{array}{l}\text { Patient-related } \\
\text { Age, years* } \\
\text { Female gender } \\
\text { Body mass index* }\end{array}$ & $\begin{array}{c}77.46(9.68) \\
59.34 \%(162) \\
27.43(5.64)\end{array}$ & $\begin{array}{c}73.65(15.33) \\
65.35 \%(413) \\
27.21(6.19)\end{array}$ & $\begin{array}{c}<0.001 \\
0.085 \\
0.334\end{array}$ \\
\hline $\begin{array}{l}\text { Comorbidities } \\
\text { Smoking } \\
\text { High blood pressure } \\
\text { Coronary artery disease } \\
\text { Diabetes } \\
\text { Dyslipidemia } \\
\text { Stroke } \\
\text { Heart failure } \\
\text { Chronic kidney failure } \\
\text { Immobility } \\
\text { Oncological disease } \\
\text { COPD } \\
\text { NSAID use } \\
\text { Corticosteroid use } \\
\text { Cilostazol use }\end{array}$ & $\begin{array}{c}5.86 \%(16) \\
76.92 \%(210) \\
18.32 \%(50) \\
16.12 \%(44) \\
80.95 \%(221) \\
17.58(48) \\
15.02 \%(41) \\
14.29 \%(39) \\
61.90 \%(169) \\
25.27 \%(69) \\
13.55 \%(37) \\
28.94 \%(79) \\
24.91 \%(68) \\
2.93 \%(8)\end{array}$ & $\begin{array}{c}7.12 \%(45) \\
54.91 \%(347) \\
5.06 \%(32) \\
7.75 \%(49) \\
30.06 \%(190) \\
6.33 \%(40) \\
7.75 \%(49) \\
9.49 \%(60) \\
57.28 \%(362) \\
30.38 \%(192) \\
9.49 \%(60) \\
21.04 \%(133) \\
24.84 \%(157) \\
1.27 \%(8)\end{array}$ & $\begin{array}{c}0.488 \\
<0.001 \\
<0.001 \\
<0.001 \\
<0.001 \\
<0.001 \\
<0.001 \\
0.034 \\
0.195 \\
0.120 \\
0.070 \\
0.010 \\
0.983 \\
0.081\end{array}$ \\
\hline $\begin{array}{l}\text { VTD-related } \\
\text { Concomitant pulmonary embolism }\end{array}$ & $23.44 \%(64)$ & $19.62 \%(124)$ & 0.193 \\
\hline
\end{tabular}

*Mean ( \pm standard deviation).

SU: statin users; NSU: non-statins users; DVT: deep vein thrombosis; COPD: chronic obstructive pulmonary disease; NSAIDs: non-steroidal anti-inflammatory drugs; VTD: venous thromboembolic disease.

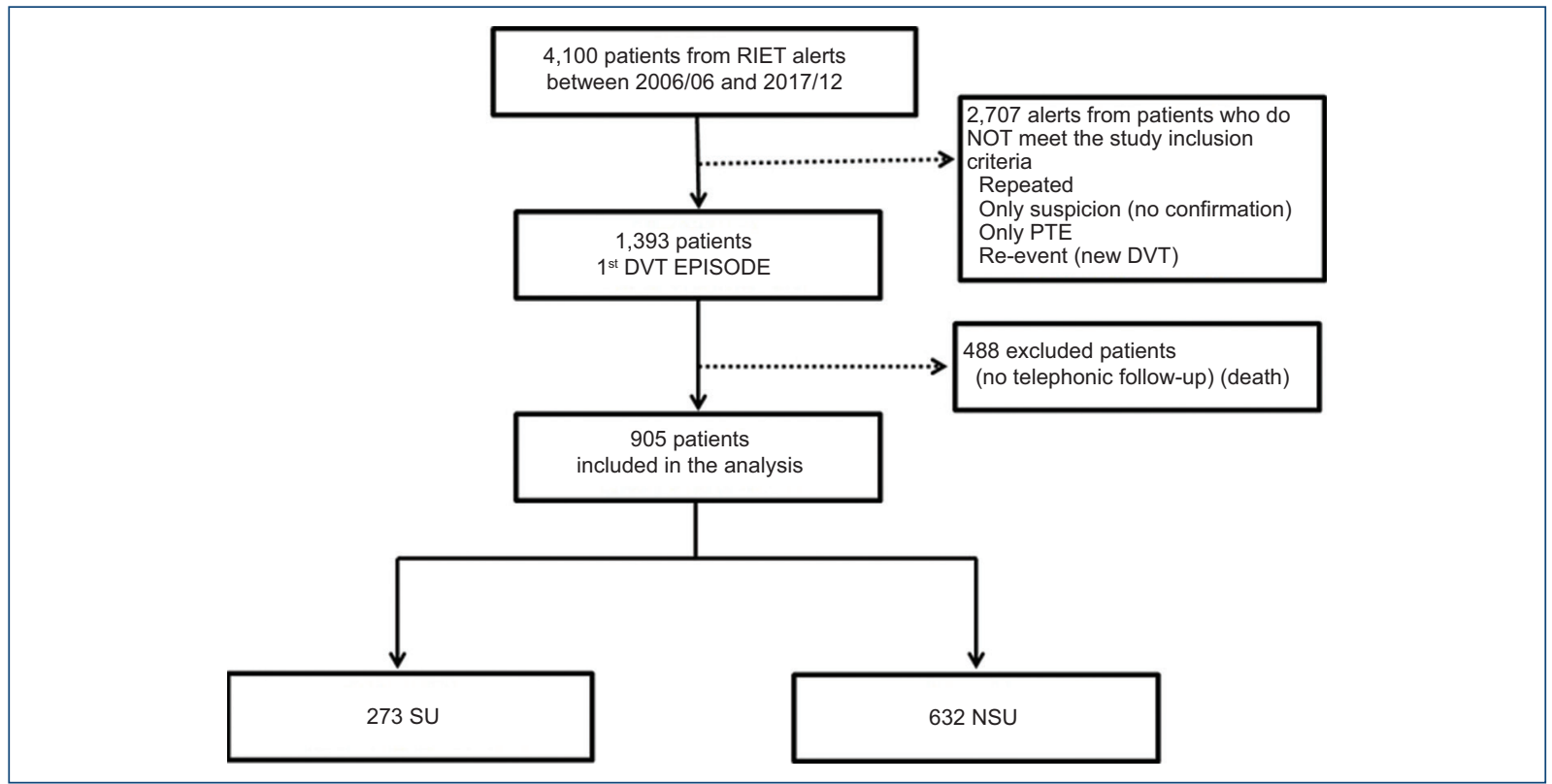

Figure 1. Flow diagram of patient inclusion in the study.

RIET: (Registro Institucional de Enfermedad TromboEmbólica): Thromboembolic Disease Institutional Registry; PTE: pulmonary thromboembolism; SU: statin users; NSU: non-statin users; DVT: deep vein thrombosis.

for SUs with regard to NSUs. Table 5 presents annual accumulated incidences for both groups. Median timeto-event could not be estimated because neither of the two groups had $50 \%$ of PTS events accumulated incidence. Median time to the development of PTS was 9 months, with 8 months in the NSU group and 
Table 3. Details on statin use in the statin users (SU) group

\begin{tabular}{|c|c|}
\hline Statin type & SU (n = 273) \\
\hline Rosuvastatin & $24.91 \%(68)$ \\
$5 \mathrm{mg}$ & $22.05 \%(15)$ \\
$10 \mathrm{mg}$ & $64.70 \%(44)$ \\
$20 \mathrm{mg}$ & $13.25 \%(9)$ \\
\hline Atorvastatin & $51.28 \%(140)$ \\
$10 \mathrm{mg}$ & $52.14 \%(73)$ \\
$20 \mathrm{mg}$ & $47.86 \%(67)$ \\
\hline Simvastatin & $23.81 \%(65)$ \\
$10 \mathrm{mg}$ & $46.15 \%(30)$ \\
$20 \mathrm{mg}$ & $47.69 \%(31)$ \\
$40 \mathrm{mg}$ & $6.16 \%(4)$ \\
\hline
\end{tabular}

Table 4. Number of events evaluated during follow-up by SU and NSU group

\begin{tabular}{|l|c|c|c|}
\hline & $\begin{array}{c}\text { SU } \\
(\mathbf{n = 2 7 3 )}\end{array}$ & $\begin{array}{c}\text { NSU } \\
(\mathbf{n}=\mathbf{6 3 2})\end{array}$ & $\mathbf{p}^{*}$ \\
\hline PTS & 18 & 51 & 0.412 \\
\hline VTDR & 30 & 68 & 0.403 \\
\hline Death & 120 & 322 & 0.047 \\
\hline $\begin{array}{l}\text { Median follow-up at last } \\
\text { date of contact, months }\end{array}$ & $\begin{array}{c}17 \text { (IIC } \\
0-44)\end{array}$ & $\begin{array}{c}15 \text { (IIC } \\
0-36.5)\end{array}$ & 0.177 \\
\hline
\end{tabular}

*Log-rank test estimated p-value.

SU: statin users; NSU: non-statins users; PTS: post-thrombotic syndrome; VTDR: venous thromboembolic disease recurrence.

Table 5. PTS cumulative incidence estimated with the Kaplan-Meier method in both SU and NSU groups

\begin{tabular}{|l|c|c|}
\hline $\begin{array}{l}\text { PTS cumulative } \\
\text { incidence (months) }\end{array}$ & $\begin{array}{c}\text { SU (\% with } \\
\mathbf{9 5 \%} \mathbf{~ C I})\end{array}$ & $\begin{array}{c}\text { NSU (\% with } \\
\mathbf{9 5} \% \mathbf{C I})\end{array}$ \\
\hline 12 & 5.03 & 4.62 \\
& $(2.54-9.85)$ & $(2.85-7.47)$ \\
\hline 24 & 7.57 & 7.9 \\
& $(4.22-13.38)$ & $(5.24-11.82)$ \\
\hline 36 & 10.69 & 12.58 \\
& $(6.05-18.52)$ & $(8.69-18.03)$ \\
\hline 48 & 12.59 & 18.57 \\
& $(7.19-21.55)$ & $(13.13-25.91)$ \\
\hline 60 & 17.19 & 22.59 \\
& $(8.92-31.65)$ & $(15.58-32.09)$ \\
\hline
\end{tabular}

SU: statin users; NSU: non-statin users; PTS: post-thrombotic syndrome; Cl: confidence interval.

11 months in SU group. Figure 2 shows the KaplanMeier graph for the development of PTS between SUs and NSUs (log-rank test: $p=0.412$ ).

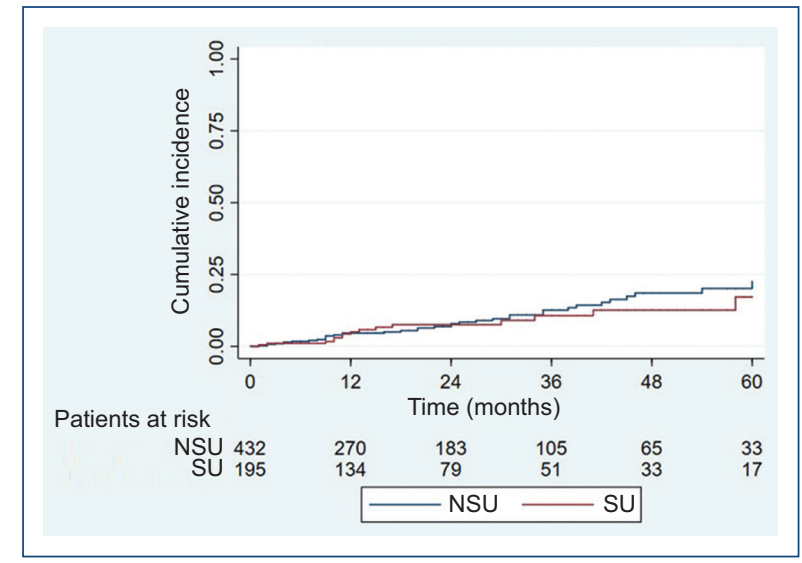

Figure 2. Cumulative PTS incidence estimated according to time for SU (red) and NSU (blue) patients. PTS: postthrombotic syndrome; SU: statin users; NCE: non-statin users.

SUs crude HR for the development of SPT was 0.78 (95\% Cl: 0.43-1.41; $p=0.414)$. SUs HR for the development of PTS adjusted for age, gender, NSAIDs, corticosteroids, immobility, anticoagulant treatment, HBP, $\mathrm{DM}, \mathrm{DLP}, \mathrm{CKF}$, coronary artery disease, stroke, CHF, and oncological disease was 0.45 (95\% Cl: 0.13-1.5; $p=0.196)$. SUs HR for the development of PTS adjusted for age, gender, NSAIDs, corticosteroids, immobility, anticoagulant treatment, oncological disease, and PS was 0.52 (95\% Cl: 0.17-1.66; $p=0.272)$.

Table 6 presents the results of the univariate and multivariate Cox regression analyses for PTS with crude and adjusted HR estimates and with their respective $95 \% \mathrm{Cl}$.

Considering competitive events as sensitivity analysis, SUs crude SHR for the development of PTS was 0.84 (95\% Cl: 0.46-1.51; $p=0.555)$. SUs sHR adjusted for age, gender, NSAIDs, corticosteroids, immobility, anticoagulant treatment, oncological disease, and PS for the development of PTS was 0.45 (95\% Cl: 0.14$1.46 ; p=0.184)$.

\section{Association between SU and death}

Table 7 shows the cumulative incidences by groups, every 12 months. Death incidence median follow-up time for the entire cohort was 15 months, with 15 months in the NSU group and 17 months in the SU group.

Figure 3 shows the Kaplan-Meier graph for mortality between SUs and NSUs (log-rank test: $p=0.046$ ). SUs crude HR for death was $0.71(95 \% \mathrm{Cl}$ : 0.5-0.99; 
Table 6. Association between statin use and PTS development. Cox regression model

\begin{tabular}{|l|c|c|c|}
\hline & HR & $95 \%$ CI & P \\
\hline Age, for each increase in 1 year & 0.99 & $(0.97-1)$ & 0.1 \\
\hline Female gender & 1.56 & $(0.86-2.84)$ & 0.144 \\
\hline NSAIDs & 0.86 & $(0.47-1.59)$ & 0.639 \\
\hline Corticosteroids & 1.18 & $(0.62-2.24)$ & 0.619 \\
\hline Immobility & 3.03 & $(1.57-5.87)$ & 0.001 \\
\hline Received anticoagulant treatment & 1.1 & $(0.32-3.8)$ & 0.883 \\
\hline Oncological disease & 0.87 & $(0.42-1.78)$ & 0.702 \\
\hline SU versus NSU crude & 0.78 & $(0.43-1.41)$ & 0.414 \\
\hline SU versus NSU adjusted & 0.45 & $(0.13-1.5)$ & 0.196 \\
\hline SU versus NSU adjusted for PS & 0.52 & $(0.17-1.66)$ & 0.272 \\
\hline
\end{tabular}

*Adjusted for age, gender, NSAIDs, corticosteroids, immobility, anticoagulant treatment, HBP, DM, dyslipidemia, CKF, coronary artery disease, stroke, $\mathrm{CHF}$, and oncological disease.

${ }^{\dagger}$ Adjusted for age, gender, NSAIDs, corticosteroids, immobility, anticoagulant treatment, oncological disease, and statin use PS.

PTS: post-thrombotic syndrome; HR: hazard ratio; Cl: confidence interval; NSAIDs: non-steroidal anti-inflammatory drugs; SU: statin users; NSU: non-statin users; PS: propensity score.

Table 7. Cumulative incidence of death estimated with the Kaplan-Meier method in both SU and NSU groups

\begin{tabular}{|l|c|c|}
\hline $\begin{array}{l}\text { Cumulative incidence } \\
\text { of death (months) }\end{array}$ & $\begin{array}{c}\text { SU (\% with } \\
95 \% \text { CI) }\end{array}$ & $\begin{array}{c}\text { NSU (\% with } \\
95 \% \text { CI) }\end{array}$ \\
\hline 12 & $11.36(7.63-16.74)$ & $14.41(11.42-18.1)$ \\
\hline 24 & $14.86(10.39-21.04)$ & $20.45(16.79-24.77)$ \\
\hline 36 & $18.58(13.26-25.7)$ & $27.56(23.09-32.7)$ \\
\hline 48 & $20.79(14.96-28.49)$ & $34.58(29.33-40.47)$ \\
\hline 60 & $27.13(19.57-36.85)$ & $36.47(30.98-42.6)$ \\
\hline
\end{tabular}

$\mathrm{Cl}$, confidence interval, SU: statin users; NSU: non-statin users.

$p=0.049$ ). SUs HR adjusted for age, gender, NSAIDs, corticosteroids, immobility, anticoagulant treatment, oncological disease, Charlson comorbidity score, and PS was 0.62 (95\% Cl: 0.4-0.98; $\mathrm{p}=0.04$ ).

\section{Discussion}

In our study, we found no association between the use of statins and the development of PTS, and since the study is pragmatic, it represents the most similar scenario to routine follow-up of patients in the real world. This type of design increases external validity, although there

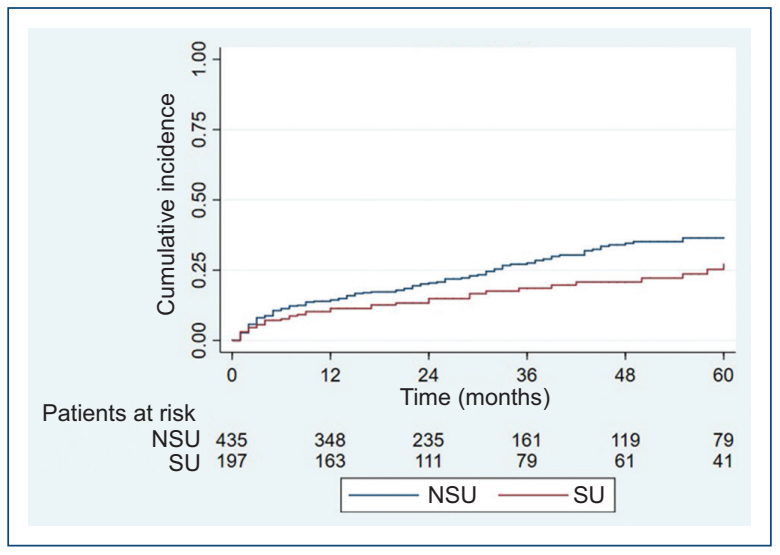

Figure 3. Mortality estimated with the Kaplan-Meier method according to time for SU (red) and NSU (blue) patients. SU: statin users; NSU: non-statin users.

is larger variability in measurements and processes (e.g., adherence, doses, use of different statins, patient comorbidities, irregular follow-up), and larger sample sizes are required. It should be noted that the great limitation of this work lies in the low statistical power based on the low incidence of PTS. Through a multiple collection strategy, a total of 69 cases were detected, 18 in the SU group and 51 in the NSU group, and only 8 were detected through the medical record, but this might explain the lack of statistical significance.

The effect of statins on VTD was observed for the $1^{\text {st }}$ time in the JUPITER study ${ }^{19}$, which as a secondary endpoint explored the effect of rosuvastatin on VTD reduction in patients with elevated C-reactive protein (CRP), showing a reduction of $43 \%$ in the risk for VTD in patients treated with rosuvastatin (OR: 0.57; $95 \% \mathrm{Cl}: 0.37-0.86)$. Although external validity is limited, it motivated different subsequent studies on the subject. Biological plausibility of the possible mechanisms that explain an association between SU and PTS are based on its definition and origin, given that it is the result of the venous hypertension that follows the development of valve incompetence, reflux, and venous obstruction. Valve incompetence is the consequence of the damage suffered by venous valves at the time of the acute thrombotic episode and venous rechanneling phase. Different inflammatory components that are among the determining factors for the development of PTS act in these phases. On one hand, microvascular endothelial cells that are metabolically active express different class 1 intracellular adhesion molecules (ICAM-1), class 1 vascular adhesion molecules (VCAM-1), and lower E-selectin expression than 
normal endothelial cells ${ }^{20}$. Surrounding leukocytes, mostly neutrophils, T lymphocytes, monocytes, and macrophages, potentiate the inflammatory response by expressing certain adhesion molecules and by secreting inflammatory mediators such as interleukin (IL) 1 , IL-6, IL-8, P-selectin, monocyte chemotactic protein 1 (MCP-1), tumor necrosis factor (TNF) beta 1 (TNF- $\beta 1$ ), and alpha (TNF- $\alpha)$. On the other hand, leukocyte cells release and activation act on interstitial cells, which as responses to mediators released by endothelial vascular cells and leukocytes, stimulate the recruitment and activation of macrophages and fibroblasts and the expression of different connective tissue proteins, with subsequent damaged tissue repair. Given that PTS is the consequence of a large inflammatory reaction, we consider it important highlighting that statins, which are lipid-lowering but have a pleiotropic and anti-inflammatory effect, could help decrease chronically generated inflammation by acting on the regulation, expression decrease, and secretion of different pro-inflammatory factors such as ICAM-1, VCAM-1, IL-1, IL-6, IL-8, TNF- $\beta 1$, and TNF- $\alpha^{6,21}$. This way, by acting on these different inflammation components, statins might decrease the development of PTS in patients who have had $\mathrm{DVT}^{8}$.

Along the same lines, San Norberto et al. carried out a trial with 234 patients diagnosed with VTD without $\mathrm{PTE}^{22}$, and as a secondary endpoint they evaluated the effect of statins on the degree of PTS. The group of patients treated with rosuvastatin showed a reduction in CRP levels and in the incidence of PTS (38.3 vs. $48.5 \% ; p=0.019$ ), after 3 months of follow-up. Unlike our study, in this one subjects had fewer comorbidities, and we included patients with concomitant PTE; VTD lower load may have favored rosuvastatin effect and explain its results, which lack statistical significance, but show an association with the same direction (statins as protective agents), which is consistent with our results (crude HR: $0.78 ; 95 \% \mathrm{Cl}$ : 0.43-1.41; $p=0.414$ ).

Regarding the detection of PTS, in the study by Ghanima et al. ${ }^{23}$ and in that by San Norberto et al., a structured clinical interview with the Villalta scale was used (with PTS being considered as a score $>5$ or presence of venous ulcer) ${ }^{22}$, while, in our study, cases were identified using an adaptation of the Villalta questionnaire $^{16}$ and by EMR systematic review. Although telephonic assessment is more feasible and practical, it is likely that it will only detect severe or symptomatic PTS cases. This difference in the detection methods might explain the difference observed for PTS incidence in our cohort, of $7.62 \%$, which is lower when compared to these studies, where it is around $40 \%$. In addition, since the frequency of PTS in our study was lower than expected, the absence of statistically significant differences could be due to a lack of power to detect differences between SUs and NSUs.

In reference to the use of statins, the statin that was most commonly used in our cohort was atorvastatin, $51.28 \%$ at a dose of $10 \mathrm{mg} / \mathrm{day}$, in contrast to other studies, which describe the use of rosuvastatin ${ }^{24,25}$.

Our results with regard to recurrent venous thromboembolic disease (RVTD) resemble those of the study by Delluc et al. ${ }^{26}$, a prospective cohort of 432 patients with a first VTD event. In the multivariate analysis, the risk of RVTD associated with exposure to statins was 1.02 (95\% Cl: 0.36-2.91), while, in our cohort, SUs adjusted HR was $0.74(95 \% \mathrm{Cl}: 0.37-1.49)$. Although in both studies the differences were not statistically significant, they selected a population with fewer comorbidities than ours, since they excluded secondary VTD. Furthermore, they carried out a more active lipid-lowering drugs use evaluation, and considered anticoagulation time and the thrombosis site, which are aspects that we could not assess.

Our results for the sensitivity analysis were consistent with the main analysis, and this agreement increases the robustness and consistency of our findings.

\section{Acknowledgments}

To all the people who collaborated in the project providing technical support, such as assistance in the writing of the manuscript, and to the department heads (Dr. Javier Pollán and Dr. Bernardo Martínez), who provided general support. This project represents the master's degree thesis in Clinical Research of the main and corresponding author for the Instituto Universitario Hospital Italiano.

\section{Funding}

The present investigation has not received any specific grant from agencies of the public, commercial, or non-profit sector.

\section{Conflicts of interest}

This research has not received specific aid from agencies of the public or commercial sectors, or non-profit entities. 


\section{Ethical disclosures}

Protection of human and animal subjects. The authors declare that the procedures that were followed adhered to the ethical standards of the responsible human experimentation committee and were in agreement with the World Medical Association and the Declaration of Helsinki.

Confidentiality of data. The authors declare that they have followed the protocols of their work center on the publication of patient data.

Right to privacy and informed consent. The authors have obtained informed consent from the patients and/or subjects referred to in the article. This document is in the possession of the corresponding author.

\section{References}

1. Gabriel Botella F, Labiós Gómez M, Portolés Reparaz O, Cabanes Vila J. Nuevos avances en el conocimiento del síndrome postrombótico. An Med Interna. 2003;20(9)

2. ISTH Steering Committee for World Thrombosis Day. Thrombosis: a major contributor to the global disease burden. J Thromb Haemost. 2014:12(10):1580-90.

3. Prandoni $P$, Lensing AW, Cogo A, Cuppini S, Villalta S, Carta M, et al. The long-term clinical course of acute deep venous thrombosis. Ann Intern Med. 1996;125(1):1-7.

4. Goldhaber SZ, Bounameaux H. Pulmonary embolism and deep vein thrombosis. Lancet. 2012;379(9828):1835-46.

5. Suematsu M, Ishimura Y, Schmid-Schönbein GW. Temporal and spatial dissociation between tissue leukocyte recruitment and cell injury in the rat postischemic skeletal muscle microcirculation. Pathophysiology. 1994;1:211.

6. Wassmann S, Nickenig G. Interrelationship of free oxygen radicals and en-dothelial dysfunction-modulation by statins. Endothelium. 2003;10(1):23-33

7. Huacuja Álvarez F, Gómez Duque M, Ortiz Vargas JC, Soberanes Ve-lázquez B, Arévalo Moreno V, Morales Villegas E, et al. Efecto de las estatinas más allá del colesterol. Rev Endocrinol Nutr. 2006;14(2):73-88.

8. Rodriguez AL, Wojcik BM, Wrobleski SK, Myers DD Jr, Wakefield TW, Diaz JA. Statins, inflammation and deep vein thrombosis: a systematic review. J Thromb Thrombolysis. 2012;33(4):371-82.
9. Luna D, Otero $P$, López Osornio A Ríos $E$, Pedernera FA, Gómez A et al. Implementación de una historia clínica electrónica ambulatoria: El Proyecto Itálica [Internet]. 6.․․ Simposio de Informática en Salud - 32 JAllO 2003. Disponible en: https://www.academia.edu/23049560/lmple-mentaci\%C3\%B3n_de_una_Historia_CI\%C3\%ADnica_Electr\%C3\%B3ni-ca_Ambulatoria_Proyecto_ITALICA

10. Plazzotta F, Luna D, González Bernaldo de Quirós F. Sistemas de infor-mación en salud: Integrando datos clínicos en diferentes escenarios y usuarios. Rev Peru Med Exp Salud Publica. 2015;32(2):343-51.

11. SNOMED International [Internet]. Disponible en: http://www.snomed.org/ snomed-ct

12. Franco M, Giussi Bordoni MV, Otero C, Landoni MC, Benitez S, Borbolla $D$, et al. Problem oriented medical record: Characterizing the use of the problem list at Hospital Italiano de Buenos Aires. Stud Health Technol Inform. 2015;216:877.

13. Luna D, Franco M, Plaza C, Otero C, Wassermann S, Gambarte ML, et al. Accuracy of an electronic problem list from primary care providers and specialists. Stud Health Technol Inform. 2013;192:417-21.

14. Plazzotta F, Otero C, Luna D, de Quiros FGB. Natural language proces-sing and inference rules as strategies for updating problem list in an electronic health record. Stud Health Technol Inform. 2013;192:1163.

15. ATC/DDD Index 2020 [Internet]. WHO Collaborating Centre for Drug Sta-tistics Methodology. Disponible en: https://www.whocc.no/atc_ddd_index/

16. Posadas-Martínez L, Pazo V, Vázquez F, Arbelbide J, Waisman G, Bernal-do de Quirós $F$, et al. Síndrome postrombótico: validación de una escala telefónica como herramienta diagnóstica. Rev Argent Med. 2014;2:33-8.

17. Zhang $X$, Zhang MJ, Fine J. A proportional hazards regression model for the subdistribution with right-censored and left-truncated competing risks data. Stat Med. 2011;30(16):1933.

18. Fine JP, Gray RJ. A proportional hazards model for the subdistribution of a competing risk. J Am Stat Assoc. 1999;94(446):496-509.

19. Rosenstein R, Parra D. Rosuvastatin. C-reactive protein, LDL cholesterol, and the JUPITER trial. Lancet. 2009;374(9683):25.

20. Weyl A, Vanscheidt W, Weiss JM, Peschen M, Schopf E, Simon J. Ex-pression of the adhesion molecules ICAM-1, VCAM-1, and E-selectin and their ligands VLA-4 and LFA-1 in chronic venous leg ulcers. J Am Acad Dermatol. 1996;34(3):418-23.

21. Mennickent CS, Bravo DM, Calvo MC, Avello LM. Pleiotropic effects of statins. Rev Med Chile. 2008:136(6):775-82.

22. San Norberto EM, Norberto EMS, Gastambide MV, Taylor JH, Gar-cíaSaiz I, Vaquero C. Effects of rosuvastatin as an adjuvant treatment for deep vein thrombosis. Vasa. 2016;45(2):133-40.

23. Ghanima W, Kleven IW, Enden T, Rosales A, Wik HS, Pederstad L, et al. Recurrent venous thrombosis, post-thrombotic syndrome and quality of life after catheter-directed thrombolysis in severe proximal deep vein thrombosis. J Thromb Haemost. 2011:9(6):1261-3.

24. Glynn RJ, Danielson E, Fonseca FAH, Genest J, Gotto AM Jr, Kastelein JJP, et al. A randomized trial of rosuvastatin in the prevention of venous thromboembolism. N Engl J Med. 2009;360(18):1851-61.

25. Kunutsor SK, Seidu S, Khunti K. Statins and primary prevention of venous thromboembolism: a systematic review and meta-analysis. Lancet Hae-matol. 2017;4(2):e83-93

26. Delluc A, Tromeur C, Le Moigne E, Nowak E, Mottier D, Le Gal G, et al. Lipid lowering drugs and the risk of recurrent venous thromboembolism. Thromb Res. 2012;130(6):859-63. 